\title{
HILGARDIA
}

A Journal of Agricultural Science Publisbed by the California Agricultural Experiment Station

CONTENTS

FACTORS INFLUENCING THE RESULTS OF FUMIGATION OF THE CALIFORNIA RED SCALE

D. L. IINDGREN

INHERITANCE OF RESISTANCE TO HYDROCYANIC ACID FUMIGATION IN THE CALIFORNIA RED SCALE

R. C. DICKSON

UNIVERSITY OF CALIFORNIA • BERKELEY, CALIFORNIA 


\section{INHERITANCE OF RESISTANCE TO HYDROCYANIC ACID FUMIGATION IN THE CALIFORNIA RED SCALE}

R. C. DICKSON 



\title{
INHERITANCE OF RESISTANCE TO HYDROCYANIC ACID FUMIGATION IN THE CALIFORNIA RED SCALE ${ }^{1,2}$
}

\author{
R. C. DICKSON ${ }^{3}$
}

\section{INTRODUCTION}

Aвоuт 1914, the California red scale, Aonidiella aurantii (Mask.), was first observed to have become difficult to kill by hydrocyanic acid fumigation in a small district at Corona, California (Quayle, 1938, p. 187). Since that time, resistance of red scale to fumigation has increased throughout many of the citrus areas of southern California.

In 1936, the two recognized strains of red scale, "resistant" and "nonresistant," were obtained from Corona and Glendora, California, respectively, and were grown in separate insectproof rooms in the insectary at the Citrus Experiment Station. Banana squash and, later, grapefruits were infested from these stocks at intervals of approximately six months and fumigated to determine whether these strains would maintain their difference in susceptibility to HCN. Preliminary results (Quayle, 1938) showed that the differences were maintained through several generations; later results have confirmed this (Lindgren, 1941) and show that resistance to fumigation is inherited.

The experiment described in this paper was conducted to determine how resistance to HCN fumigation is inherited in the red scale.

\section{REVIEW OF LITERATURE}

Hough (1928), working with two strains of codling moth which differed in their ability to enter arsenic-sprayed apples, crossed the two strains and found the $\mathrm{F}_{1}$ hybrids intermediate between the parental strains in this regard. Later he reported (Hough, 1929) that the $\mathrm{F}_{1}$ hybrids from the reciprocal crosses were similar and that the $\mathrm{F}_{2}$ resembled the $\mathrm{F}_{1}$. By 1934 he had carried the progeny of both crosses to the $F_{10}$ and still found them similar and intermediate between the parental strains (Hough, 1934). $F_{5}$ moths from these crosses were backcrossed with each parental strain, and in each case the resulting progeny were found to approach, but not to be identical with, the introduced parental strain in ability to enter arsenic-sprayed fruit.

\footnotetext{
${ }^{1}$ Received for publication January 23, 1940.

${ }^{2}$ Paper no. 419, University of California Citrus Experiment Station, Riverside, California.

${ }^{3}$ Laboratory Assistant in Entomology in the Experiment Station.

"See "Literature Cited" at the end of the paper for complete data on citations, which are referred to in the text by author and date of publication.
} 
Gough (1939) selected certain strains of the confused flour beetle, Tribolium confusum Duv., which differed in susceptibility to HCN fumigation and found that they retained their relative differences through seven generations.

\section{EXPERIMENTAL PROCEDURE}

The red-scale crosses were made by the mass-crossing method. All insects used in these experiments were grown on grapefruits in the insectary at $80^{\circ} \mathrm{F}$ and about 80 per cent relative humidity. All fruits were numbered and dated with India ink.

Grapefruits infested with red scale of the type desired for female parents were taken from the insectary rearing room 14 days after infestation, and all the males were removed from the fruits, by means of a needle, during the second, prepupal, and pupal stages. The complete removal of males required several inspections on successive days. Before the time for the first males to emerge (approximately 20 days), the button, or calyx, on each fruit was covered with paraffin to prevent any males under it from escaping. Throughout this period and subsequently, the grapefruits bearing these source insects were kept in small insectproof cages. When all the males had been removed from a grapefruit, it was placed in a cage with a grapefruit bearing red scale of the type desired for male parents. The insects on the second grapefruit were a day or two younger than those on the first fruit, so that when the males emerged, all the females on the first grapefruit were ready for fertilization. The second grapefruit was removed as soon as all the males had emerged. Since there is no reproduction without fertilization in this species, the only females to produce young were those fertilized by males from the second grapefruit. Thus all the young obtained were hybrids.

The grapefruits bearing the fertilized female parents were held until these insects began to produce young. The hybrid crawlers were then brushed from each source fruit to clean fruit two or three times daily for a period of about three weeks. Most of the fruits infested with hybrids in this way were held until the female scales on them reached maturity ${ }^{5}$ and were then fumigated with $\mathrm{HCN}$ for 40 minutes at $75^{\circ} \mathrm{F}$ in a 100 cubic-foot fumatorium; the rest of the fruits were used in making further crosses. Dosages of $1 \mathrm{cc}$ or 2 ec of $\mathrm{HCN}$ were used in each fumigation. The fumigated fruits were held for two weeks, and the scales were

\footnotetext{
${ }^{5}$ Mature female scales were used in these experiments because it was necessary to use insects produced on several successive days in order to fumigate insects in sufficient numbers to secure significant data, and Lindgren's (1941) findings made the use of younger insects in this way seem inadvisable. Red-scale males reared under the conditions of these experiments emerge as winged adults at 20 to 22 days of age, immediately fertilize females, and die; consequently, by the time the females reached maturity, at the age of approximately 38 days, no males were present.
} 
then counted to determine the total number fumigated and the number of survivors. A total of 100,063 insects, of which 62,347 were hybrids, were fumigated and counted in these experiments.

The first crosses made were between the resistant $(R)$ and the nonresistant $(N R)$ strains to get the $\mathrm{F}_{1}$. Both $R q \times N R \delta^{\lambda}$ and $N R q \times R \delta^{\lambda}$ crosses were made. These $F_{1}$ insects were fumigated together with insects of both parental strains.

Subsequent crosses were made between the $\mathrm{F}_{1}$ red scales, first, by allowing females to be fertilized by males from the same fruit, and then by the mass-crossing method outlined in the second paragraph of this section.

Production of red-scale hybrids was timed so that all classes which were to be compared could be fumigated together. This allowed direct comparisons uninfluenced by variations in successive fumigations.

All data were evaluated by the use of the $t$ test (Snedecor, 1937).

\section{EXPERIMENTAL RESULTS}

Results obtained by fumigating the $\mathrm{F}_{1}$ females together with the females of the $R$ and $N R$ parental strains are shown in table 1 . There is no significant difference between the percentage survival of the $F_{1}$ females obtained from the $R+\times N R \sigma^{\gamma}$ cross and that of the $\mathrm{F}_{1}$ females from the $N R q \times R \delta^{\lambda}$ cross. The $\mathrm{F}_{1}$ females show an intermediate survival somewhat closer to that of the resistant strain than to that of the nonresistant strain, but definitely distinct from either.

There are four classes of $\mathrm{F}_{2}$ females. The keys $R-S, N R-X, N R-S$, and $R-X$ are used here and in table 1 and figure 1 to identify the classes of $\mathrm{F}_{2}$ females. These were useful in the experimental work and are included to facilitate comparison of data presented. The first part of each key, $R$ or $N R$, refers to the $\mathrm{F}_{1}$ mothers and identifies them as having had resistant $(R)$ or nonresistant $(N R)$ mothers. The rest of the key, $S$ or $X$, indicates the type of males with which the $\mathrm{F}_{1}$ mothers were crossed. $S$ indicates that the cross between the $\mathrm{F}_{1}$ parents was direct; that is, that the $F_{1}$ fathers and $F_{1}$ mothers were identical in ancestry. Similarly, an $X$ indicates that the $\mathrm{F}_{1}$ males used to fertilize the $\mathrm{F}_{1}$ mothers were from the reciprocal cross. The pedigrees of the four classes of $\mathrm{F}_{2}$ females are as follows :

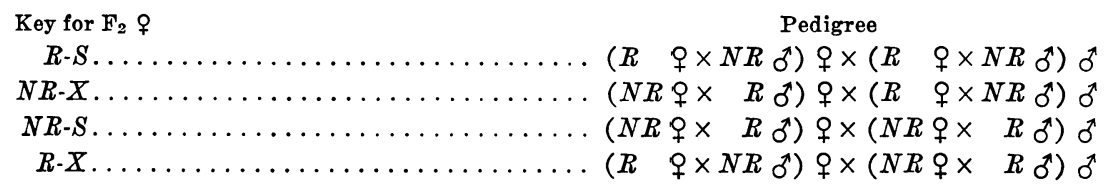

The results of fumigating the females of the $\mathrm{F}_{2}$ hybrids together with 
those of the $\mathrm{F}_{1}$ hybrids and of the parental types are shown in table 1 and in the histogram, figure 1 . These data show that the females of the $R-S$ and of the $N R-X \mathrm{~F}_{2}$ hybrid populations are not significantly different in percentage survival and are practically the same as the average of the percentage survivals of the $R$ and the $\mathrm{F}_{1}$. Similarly, the percentage

\section{TABLE 1}

Comparative Results of Fumigation of Mature California Red-Scale Females : Resistant and Nonresistant Strains, Reciprocal $\mathrm{F}_{1}$ Hybrids, and Four Classes of $\mathrm{F}_{2}$ Hybrids

\begin{tabular}{c|c|c|c|c|}
\hline Class of scale* & $\begin{array}{c}\text { Number } \\
\text { of fumi- } \\
\text { gations }\end{array}$ & $\begin{array}{c}\text { Mean } \\
\text { average con- } \\
\text { centration } \\
\text { of HCN } \\
\mathrm{mg} / \mathrm{l}\end{array}$ & $\begin{array}{c}\text { Total } \\
\text { number } \\
\text { of } \\
\text { insects } \\
\text { fumigated }\end{array}$ & $\begin{array}{c}\text { Mean } \\
\text { per cent } \\
\text { survival }\end{array}$ \\
\hline
\end{tabular}

$\mathrm{HCN}, 1 \mathrm{cc}$ per $100 \mathrm{cu}$. ft. for 40 minutes at $75^{\circ} \mathrm{F}$

\begin{tabular}{|c|c|c|c|c|}
\hline$R$, resistant $\ldots \ldots \ldots \ldots \ldots \ldots \ldots \ldots \ldots \ldots \ldots$ & 12 & 0.188 & 12,088 & 45.43 \\
\hline$N R$, nonresistant. $\ldots \ldots \ldots \ldots \ldots \ldots \ldots \ldots \ldots$ & 12 & 0.188 & 10,493 & 4.06 \\
\hline $\mathbf{F}_{1}, R \& \times N R_{\sigma^{\prime}} \ldots \ldots \ldots \ldots \ldots \ldots \ldots \ldots \ldots$ & 11 & 0.188 & 4,976 & 31.53 \\
\hline 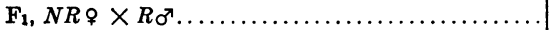 & 11 & 0.188 & 9,311 & 33.38 \\
\hline Average of two $F_{1}$ classes....... & . & $\ldots$ & .. & 32.45 \\
\hline Average, $R$ and $F_{1} \ldots \ldots \ldots \ldots \ldots$ & . & $\ldots$. & $\cdots$ & 38.94 \\
\hline Average, $N R$ and $F_{1} \ldots \ldots \ldots \ldots \ldots$ & . & $\cdots \cdots$ & $\ldots \ldots$ & 18.26 \\
\hline$R-S,\left(R \% \times N R \sigma^{\top}\right) \% \times\left(R \% \times N R \sigma^{7}\right) \sigma^{7} \ldots$. & 7 & 0.182 & 8,141 & 38.18 \\
\hline$N R-X,\left(N R \% \times R \sigma^{\top}\right) \% \times\left(R \% \times N R \sigma^{7}\right) \sigma^{\top} .$. & 4 & 0.176 & 1,591 & 33.93 \\
\hline$N R-S ;\left(N R \% \times R \sigma^{7}\right) \% \times\left(N R \% \times R \sigma^{7}\right) \sigma^{\top} \ldots$ & 7 & 0.182 & 5,871 & $\cdot 17.25$ \\
\hline$R-X,\left(R \% \times N R \sigma^{\top}\right) \% \times\left(N R \% \times R \sigma^{\top}\right) \sigma^{\top} \ldots .$. & 4 & 0.176 & 2,321 & 17.87 \\
\hline
\end{tabular}

$\mathrm{HCN}, 2 \mathrm{cc}$ per $100 \mathrm{cu}$. ft. for 40 minutes at $75^{\circ} \mathrm{F}$

\begin{tabular}{|c|c|c|c|c|}
\hline$R$, resistant............... & 9 & 0.351 & 7,755 & 22.37 \\
\hline 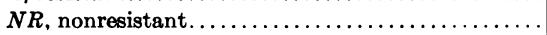 & 9 & 0.351 & 7,380 & 0.75 \\
\hline 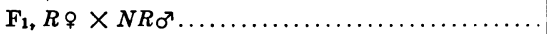 & 8 & 0.349 & 3,348 & 13.12 \\
\hline 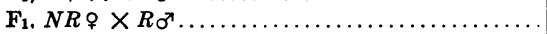 & 9 & 0.347 & 6,439 & 12.39 \\
\hline Average of two $F_{1}$ classes $\ldots \ldots \ldots \ldots \ldots \ldots \ldots$ & . & $\ldots \ldots$ & $\ldots \ldots$ & 12.75 \\
\hline Average, $R$ and $F_{1} \ldots \ldots \ldots \ldots \ldots \ldots \ldots \ldots$ & . & $\ldots \ldots$ & $\ldots \ldots$ & 17.56 \\
\hline Average, $N R$ and $F_{1} \ldots \ldots \ldots \ldots \ldots \ldots$ & $\ldots$ & $\ldots \ldots$ & $\ldots$. & 6.75 \\
\hline$R-S,\left(R \% \times N R \sigma^{\top}\right) \% \times\left(R \% \times N R \sigma^{\top}\right) \sigma^{\top} \ldots \ldots \ldots$ & 6 & 0.351 & 7,320 & 17.77 \\
\hline$N R-X,\left(N R \% \times R \sigma^{\top}\right) \% \times\left(R \% \times N R \sigma^{7}\right) \sigma^{7} \ldots \ldots \ldots$ & 4 & 0.363 & 2,377 & 18.39 \\
\hline$N R-S,\left(N R \% \times R \sigma^{\top}\right) \% \times\left(N R \% \times R \sigma^{\top}\right) \sigma^{\top} \ldots \ldots \ldots$ & 6 & 0.351 & 7,288 & 7.04 \\
\hline$R-X,\left(R \% \times N R \sigma^{\top}\right) \% \times\left(N R \% \times R \sigma^{\top}\right) \sigma^{7} \ldots$ & 4 & 0.363 & 3,364 & 7.48 \\
\hline
\end{tabular}

* For explanation of the keys, $R-S, N R-X, N R-S$, and $R-X$, used in this column to identify the four classes of $\mathrm{F}_{2}$ females, see text page 517 .

survivals of the females of the $N R-S$ and of the $R-X \mathrm{~F}_{2}$ hybrid populations are not significantly different and are practically the same as the average of the percentage survivals of the $N R$ and the $F_{1}$. The percentage survival obtained by fumigating the females of the $N R-X$ $\mathrm{F}_{2}$ hybrid population with 1 ce of $\mathrm{HCN}$ is somewhat lower than expected, but this discrepancy may be ignored in the light of the other results. 


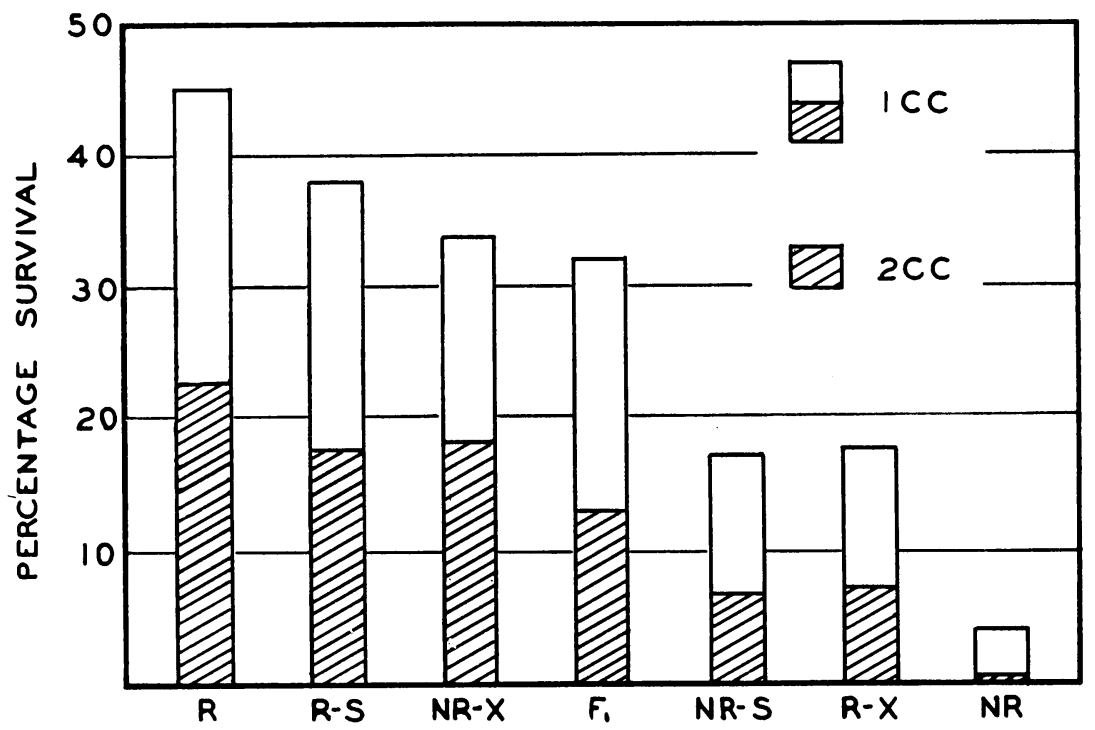

Fig. 1.-Mean percentage survival of adult females of parental strains and of the several classes of hybrid California red scale fumigated with 1 ec and 2 ce of HCN per 100 cubic feet for 40 minutes at $75^{\circ} \mathrm{F}$. $R$, resistant; $N R$, nonresistant. Explanation of the keys, $R-S, N R-X, N R-S$, and $R-X$, in text (p. 517).

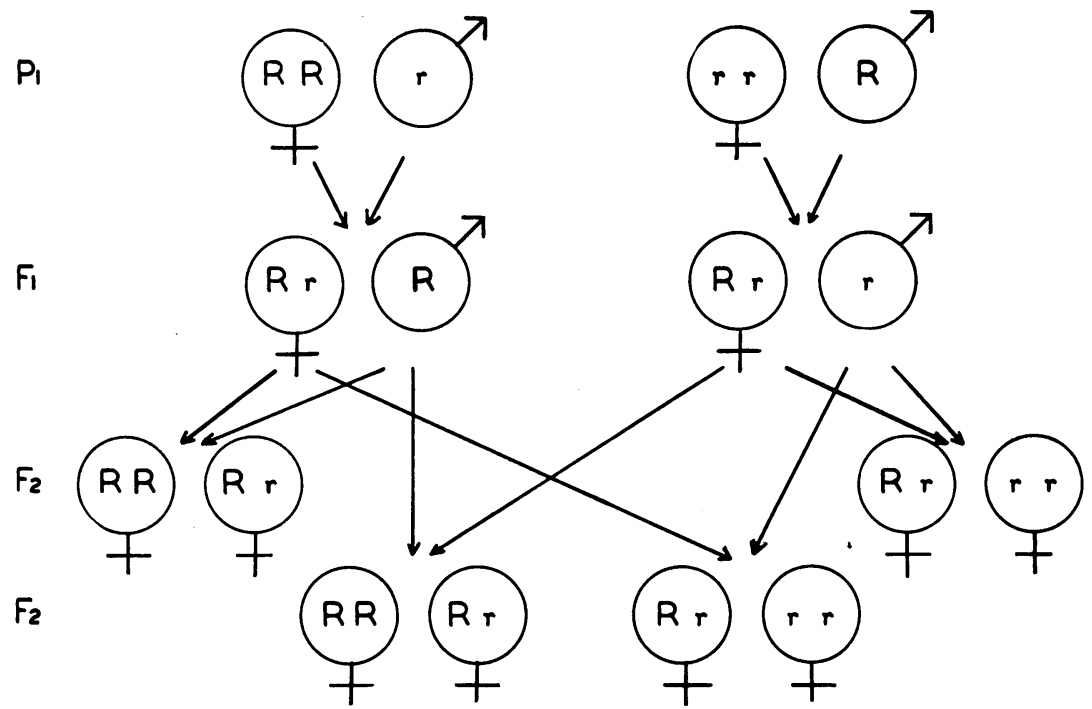

Fig. 2.-Diagram of the inheritance of the factors affecting resistance to HCN fumigation in all the red-scale crosses discussed in this paper. $R$, factor for resistance; $r$, factor for lack of resistance. 
The common parental type for $R-S$ and $N R-X$ is that of the father; the same is true for $N R-S$ and $R-X$. Therefore, the difference between the two pairs must be due to the difference in genetic composition of these $\mathrm{F}_{1}$ males. Each of the $\mathrm{F}_{2}$ hybrid populations exhibited a resistance to $\mathrm{HCN}$ intermediate between that of the $\mathrm{F}_{1}$ and that of the strain to which their paternal grandmothers belonged. These facts strongly suggest a sex-linked inheritance and the presence of a major gene affecting resistance in the $X$-chromosome. A diagram of the inheritance of resistance on this basis is shown in figure 2. This fits the known facts exactly. A less likely possibility is that resistance is due to a group of closely linked genes carried in the $X$-chromosome.

The $F_{1}$ females carry genes affecting resistance derived from both parents, and, as has been shown, dominance is incomplete. The $\mathrm{F}_{1}$ males carry only that gene affecting resistance derived from their mothers. One half of each group of $\mathrm{F}_{2}$ females consists of individuals identical with their $\mathrm{F}_{1}$ mothers and one half, of individuals identical with their paternal grandmothers. Resistance to $\mathrm{HCN}$ in red scale is thus shown to be very probably due to one gene of a pair carried by the $X$-chromosomes.

\section{DISCUSSION}

It is probable that while most of the red scales introduced into California were "normally" susceptible to $\mathrm{HCN}$ fumigation, a few carried a factor that would enable a large percentage of their descendants to survive HCN fumigation. A less likely alternative is that the resistance factor arose by mutation after fumigation of red scale began. In either case, the increase in resistance shown by field populations of this insect has been brought about by the preferential survival of those individuals which carried the resistance factor. With continued fumigation, this process will continue until practically all red scales are homozygous for resistance and are therefore of what is called the "pure resistant" strain. It is probable that the red scales in certain groves are now approaching this condition (Lindgren, 1941) and that once this condition is reached, there will be no appreciable increase in resistance to fumigation unless an auxiliary factor appears.

The original discovery of what are now called "sex chromosomes" was made in the hemipteron Pyrrhocoris apterus L. by Henking (1891). Schrader (1928) tabulates the work of many authors on the sex chromosomes of various insects, listing 107 species of Hemiptera and 51 species of Homoptera. In each of these groups both the $X X \uparrow, X Y \AA$ and the $X X$ 으 $X O{ }^{\pi}$ conditions are shown to exist. Therefore, the mechanism of inheritance indicated for the California red scale by the results reported in this paper is present in the group to which this insect belongs. 
Schrader has studied the chromosome configuration in California redscale embryos and states ${ }^{6}$ that there are eight chromosomes, all similar. The sex of the embryos studied was not known, but in all probability both males and females were observed. Apparently, then, the $X X q$, $X Y \sigma^{\lambda}$ condition is present in this species, the $X$ - and $Y$-chromosomes being similar or identical in appearance.

\section{SUMMARY}

Resistance to HCN fumigation in California red scale depends on a single gene (or group of closely linked genes) in the $X$-chromosome and is therefore sex-linked.

Crosses were made by the mass-crossing method between resistant and nonresistant strains. Reciprocal $\mathrm{F}_{1}$ crosses and four classes of $\mathrm{F}_{2}$ crosses were made. These were all fumigated together with the parental strains.

The $\mathrm{F}_{1}$ females were intermediate in percentage survival between the two parental strains.

The $\mathrm{F}_{2}$ females were intermediate in percentage survival between the $\mathrm{F}_{1}$ females and that strain to which their paternal grandmothers belonged.

Although the red scale was relatively easy to kill by $\mathrm{HCN}$ fumigation in the early use of this method of control in California, the red-scale population probably contained individuals in which the resistance factor was present. The regular control of red scale by HCN fumigation increased the percentage of resistant individuals in the population because of their preferential survival. With continued fumigation, the red scale will become generally resistant to such control until practically all the population is of the pure resistant strain. Once this condition is reached, there should be no appreciable increase in resistance.

\section{ACKNOWLEDGMENTS}

The author wishes to express appreciation for advice and assistance given by Professor Theodosius Dobzhansky, of Columbia University, and by Professor H. J. Quayle (who started the original work on the problem), Dr. D. L. Lindgren, and Dr. C. O. Persing, of the Citrus Experiment Station.

\footnotetext{
${ }^{6}$ Schrader, Franz, in a letter to the author, October 24, 1939.
} 


\section{LITERATURE CITED}

Gougr, H. C.

1939. Factors affecting the resistance of the flour beetle, Tribolium confusum Duv., to hydrogen cyanide. Ann. Appl. Biol. 26:533-71.

HENKING, H.

1891. Untersuchungen über die ersten Entwicklungsvorgänge in den Eiern der Insekten. II. Über Spermatogenese und deren Beziehung zur Eientwicklung bei Pyrrhocoris apterus L. Ztschr. f. Wiss. Zool. 51:685-736. (Original not seen by this author; cited by Schrader, 1928.)

\section{HOUGH, WALTER S.}

1928. Relative resistance to arsenical poisoning of two codling moth strains. Jour. Econ. Ent. 21:325-29.

1929. Studies of the relative resistance to arsenical poisoning of different strains of codling-moth larvae. Jour. Agr. Res. 38:245-56.

1934. Colorado and Virginia strains of codling moth in relation to their ability to enter sprayed and unsprayed apples. Jour. Agr. Res. 48:533-53.

LINDGREN, D. L.

1941. Factors influencing the results of fumigation of the California red seale. Hilgardia $13(9): 491-511$.

QUAYLE, H. J.

1938. The development of resistance to hydrocyanic acid in certain seale insects. Hilgardia 11(5):183-210.

Schrader, Franz.

1928. The sex chromosomes. 194 p. Gebrüder Borntraeger, Berlin.

SNEDECOR, G. W.

1937. Statistical methods. 341 p. Collegiate Press, Inc., Ames, Iowa. 